\title{
Strategies to gain body condition score in pasture-based dairy cows during late lactation and the far-off nonlactating period and their interaction with close-up dry matter intake
}

\author{
J. R. Roche, ${ }^{\star 1}$ A. Heiser,† M. D. Mitchell,‡ M. A. Crookenden,§ C. G. Walker,§ J. K. Kay, ${ }^{\star}$ M. Vailati Riboni,\# \\ J. J. Loor,\# and S. Meier* \\ *DairyNZ Limited, Private Bag 3221, Hamilton, New Zealand 3240 \\ †AgResearch, Hopkirk Research Institute, Grasslands Research Centre, Palmerston North, New Zealand 4442 \\ fUniversity of Queensland, Centre for Clinical Research, Royal Brisbane \& Women's Hospital Campus, Herston, Queensland, Australia 4029 \\ §DairyNZ Limited, c/o University of Auckland, 3A Symonds St., Auckland, New Zealand 1010 \\ \#Department of Animal Sciences, University of Illinois, Urbana 61801
}

\begin{abstract}
In pasture-based systems, cows are generally thinner at the end of lactation than cows fed total mixed rations and, as a result, over-feeding of metabolizable energy (ME) during the far-off nonlactating period is a standard management policy to achieve optimum calving body condition score (BCS). An alternative would be to manage cows to gain BCS through late lactation, such that cows ended lactation close to optimum calving BCS and maintenance of BCS through to calving. We sought to quantify the effect of moderate or excessive ME intakes during the far-off nonlactating period in cows that had been managed to gain or maintain BCS through late lactation and whether the far-off management strategy interacted with close-up level of feeding. Effects on milk production and circulating indicators of energy balance and metabolic health in early lactation were evaluated. A herd of 150 cows was randomly assigned to 1 of 2 feeding levels in late lactation to achieve a low and high BCS at the time of dryoff (approximately 4.25 and 5.0 on a 10-point scale). Following dry-off, both herds were managed to achieve a BCS of 5.0 one month before calving; this involved controlled feeding (i.e., maintenance) and over-feeding of ME during the far-off dry period. Within each far-off feeding-level treatment, cows were offered 65, 90, or $120 \%$ of their pre-calving ME requirements for $3 \mathrm{wk}$ pre-calving in a $2 \times 3$ factorial arrangement (i.e., 25 cows/treatment). Body weight and BCS were measured weekly before and after calving, and milk production was measured weekly until wk 7 postcalving. Blood samples were collected weekly for 4 wk pre-calving
\end{abstract}

Received June 11, 2016.

Accepted October 11, 2016.

${ }^{1}$ Corresponding author: john.roche@dairynz.co.nz and 5 wk postcalving, and on d $0,1,2,3$, and 4 relative to calving, and analyzed for indicators of energy balance (e.g., blood fatty acids, $\beta$-hydroxybutyrate), calcium status, and inflammatory state. No interaction was observed between far-off and close-up feeding levels. Over-feeding of ME to low BCS cows during the far-off nonlactating period reduced blood fatty acid and $\beta$-hydroxybutyrate concentrations in early lactation, and increased blood albumin to globulin ratio compared with cows that were dried off close to recommended calving BCS and control-fed during the far-off dry period. Cows consuming $65 \%$ of their ME requirements during the close-up period had lower fatty acids and $\beta$-hydroxybutyrate in early lactation, but produced less milk, particularly during the first 21 d of lactation, had more than 3-fold greater concentration of haptoglobin immediately postcalving, and had a lower blood cholesterol concentration and albumin to globulin ratio, when compared with cows offered 90 or $120 \%$ of their ME requirements. Collectively, these measurements indicate that a severe restriction $(<70 \%$ of $\mathrm{ME}$ requirements) during the close-up nonlactating period increases the risk of disease in early lactation and reduces milk production. In summary, far-off overfeeding of ME to cows that needed to gain BCS did not influence peripartum metabolic health in grazing dairy cows, but restricting cows below $70 \% \mathrm{ME}$ requirements during the close-up transition period resulted in a blood profile indicative of greater inflammation.

Key words: transition cow, health, welfare, hypocalcemia

\section{INTRODUCTION}

For almost a century, it has been accepted that appropriate nutrition management of the close-up transition dairy cow ( $<4 \mathrm{wk}$ before calving) involved the provision of ad libitum access to energy-dense feeds during 
the weeks before calving (Boutflour, 1928), thereby ensuring that cows did not lose condition pre-calving. This was supported by epidemiological analyses (Dyk, 1995; Sheehy et al., 2014) that indicated a positive association between elevated fatty acid concentrations or greater BCS loss in close-up transition dairy cows and the incidence of postpartum metabolic and infectious diseases.

More recently, studies designed to generate a small, controlled release of fatty acids pre-calving did not identify metabolic profiles consistent with those reported in the epidemiological studies (Agenas et al., 2003; Holtenius et al., 2003; Douglas et al., 2006; Loor et al., 2006). In fact, postcalving energy balance and indicators of metabolic health and immune function were, in general, improved when ME intake was less than requirements and blood fatty acid concentrations were elevated before calving (Douglas et al., 2006; Loor et al., 2006; Roche et al., 2005, 2015). In contrast, Hutton and Parker (1973), Roche et al. (2005), and Roche (2007) reported a lower milk production from cows that were severely restricted ( $\sim 50 \%$ of $\mathrm{ME}$ requirements) during the month pre-calving, indicating that a threshold level of ME restriction for close-up cows exists, below which production and, possibly, cow health may be adversely affected postcalving. Considering that ME intakes between 75 and $100 \%$ of their requirements have been deemed advantageous to indicators of health (Douglas et al., 2006; Loor et al., 2006; Roche et al., $2005,2015)$, such a threshold must be between 50 and $75 \%$ of requirements.

To further complicate nutritional management of the transition cow, the effects of close-up feeding level on metabolic health and immune function appear to be dependent on cow BCS (Heiser et al., 2015; Roche et al., 2015). Optimum calving BCS has been defined as a BCS of 5.0 on a 10-point scale (Roche et al., 2009); fatter cows (i.e., BCS $\geq 5.0$ on the 10-point scale) benefit from the pre-calving $\mathrm{ME}$ restriction (i.e., restricted to $75-100 \%$ of ME requirements), but thinner cows (i.e., BCS $\leq 4.0$ on the 10-point scale) profiled greater inflammation and immune dysfunction when exposed to the same restriction pre-calving. To achieve calving BCS targets (Roche et al., 2009), cows have to consume ME in excess of requirements during the far-off nonlactating period ( $>4 \mathrm{wk}$ before calving). This is particularly true in pasture-based systems, where cows are thinner at the end of lactation compared with counterparts fed TMR (Roche et al., 2007). Dann et al. (2006) reported that energy intake in excess of requirements during the far-off nonlactating period ( $\sim 28-56 \mathrm{~d}$ pre-calving) resulted in an increased risk of metabolic dysfunction during early lactation; cows fed $150 \%$ of their $\mathrm{NE}_{\mathrm{L}}$ requirements during the far-off nonlactating period had lower DMI, a more severe negative energy balance, and greater serum concentrations of fatty acids and BHB during the first 10 DIM. These effects are similar to the reported effects of excess ME intake during the closeup period (Douglas et al., 2006; Roche et al., 2015). However, the far-off treatment diet also resulted in a significant difference in calving BCS, a known contributor to postcalving DMI and metabolic state (Roche et al., 2013).

We hypothesized that the putative detrimental effect of over-feeding during the far-off nonlactating period was, in fact, an interaction with calving BCS, such that over-feeding would not have negative metabolic consequences in moderately conditioned cows at calving. In addition, we hypothesized that there is a threshold restriction of ME in the close-up period, below which cows will be negatively affected during early lactation. Therefore, the objectives of this experiment were 3 -fold: in a pasture-based seasonal calving system, to determine if (1) excessive ME intake during the faroff nonlactating period of cows that need to gain BCS before calving alters the metabolic profile of optimally conditioned cows in a way that would increase the risk of metabolic disorders in early lactation; (2) restricting cows to two-thirds of their ME requirements during the close-up transition period would reduce milk production and negatively affect indicators of health; and (3) an interaction is present between far-off and close-up ME intake on milk production and indicators of cow metabolic health.

\section{MATERIALS AND METHODS}

The Ruakura Animal Ethics Committee (Hamilton, New Zealand) approved all animal manipulations in accordance with the New Zealand Animal Welfare Act (1999). The experiment was undertaken at the DairyNZ Lye Farm facility, Hamilton, New Zealand $\left(37^{\circ} 46^{\prime} \mathrm{S} 175^{\circ} 18^{\prime} \mathrm{E}\right)$ between January and October 2014.

A group of 170 mid-lactation dairy cows of mixed age and breed (Holstein-Friesian, Jersey, Holstein-Friesian $\times$ Jersey) were considered as candidates for the experiment. From these, 150 cows that passed a veterinary clinical examination were enrolled in the experiment $\sim 20$ wk before planned start of calving. Cows were allocated randomly to 1 of 2 treatment groups (75 cows per group). All cows were dried off $79 \pm 9.5 \mathrm{~d}$ before calving.

Treatments were designed to have 2 feeding levels during the far-off nonlactating period (i.e., 80 to $40 \mathrm{~d}$ before calving) but a similar BCS at calving. To achieve this, the treatment groups needed to be at different $\mathrm{BCS}$ at the end of lactation. One of the treatment groups was managed to gain very little BCS $(<0.25$ 
BCS units; all BCS units in 10-point scale, unless otherwise stated; Roche et al., 2004) during the last $8 \mathrm{wk}$ of lactation and 0.75 to 1.0 BCS units in the $7 \mathrm{wk}$ after the completion of lactation (i.e., over-feeding during the far-off nonlactating period; far-off_over-fed). In comparison, the other group was managed to gain approximately 0.5 to $0.75 \mathrm{BCS}$ units during the last 8 wk of lactation, so that they had $<0.25$ BCS units to gain in the $7 \mathrm{wk}$ after the completion of lactation (i.e., controlled feeding during the far-off nonlactating period; far-off_control-fed).

From approximately $3 \mathrm{wk}$ before calving (i.e., closeup nonlactating period), cows within each BCS gain group were randomly assigned to 1 of 3 levels of ME intake in a $2 \times 3$ factorial arrangement of treatments. Feed allowances were managed to achieve 3 levels of ME intake up until calving (65, 90, and $120 \%$ of estimated $\mathrm{ME}$ requirements; $1.05 \mathrm{MJ}$ of $\mathrm{ME} / \mathrm{kg}$ of $\mathrm{BW}^{0.75}$; Roche et al., 2005: Feed65, Feed90, and Feed120, respectively). Cows were allocated to treatment twice per week based on expected calving date. Although cow allocation to treatment was random, groups were assessed to ensure they were balanced for age, breed, BCS at the time of enrolment, and expected calving date.

\section{Approach to Establish Treatment Groups}

In late-lactation ( $\sim 215$ DIM), feeding levels were manipulated with the intention of generating the 2 BCS treatment groups $(\mathrm{n}=75)$ before the end of lactation similar to methods employed by Roche et al. (2013). During this BCS establishment period, 3 groups of cows were managed separately to achieve the treatment target BCS at dry-off by being assigned to gain, maintain, or lose BCS groups. Cows in all groups grazed an allowance of fresh pasture and were supplemented with pasture silage, corn silage, and palm kernel extract (Tables 1 and 2).

Because the timing of accelerated BCS gain differed between the far-off_over-fed and far-off_control-fed groups, so did the DMI during the period of accelerated $\mathrm{BCS}$ gain and maintenance feeding.

- During late lactation, far-off_control-fed treatment cows consumed $17.7 \mathrm{~kg}$ of $\mathrm{DM} / \mathrm{d}$ (i.e., their period of accelerated gain), whereas the faroff_over-fed treatment cows consumed $10.3 \mathrm{~kg}$ of $\mathrm{DM} / \mathrm{d}$.

- During the far-off nonlactating period, the faroff_control-fed treatment cows consumed $8.4 \mathrm{~kg}$ of DM/d, whereas the far-off_over-fed treatment cows consumed $14.1 \mathrm{~kg}$ of DM/d (i.e., their period of accelerated gain).
Blood was sampled monthly to ensure fatty acids and BHB were within normal ranges (Gribbles Veterinary Pathology, Hamilton, New Zealand).

From $19 \pm 5.4 \mathrm{~d}$ pre-calving, cows were allocated to their assigned feeding level treatment on 1 of $2 \mathrm{~d} /$ wk. Cows were offered fresh pasture at 65, 90, 120\% of their estimated ME requirements $(1.05 \mathrm{MJ} / \mathrm{kg}$ of $\mathrm{BW}^{0.75}$; Roche et al., 2005). To achieve different pasture allowances and, hence, DMI, different-sized areas were allotted to cows in each treatment group pre-calving, with area size/group declining as cows calved and were removed from the treatment area. Area allocation $\left(\mathrm{m}^{2} /\right.$ cow) was calculated by multiplying pre-grazing pasture mass per $\mathrm{m}^{2}$ by the desired allowance per cow (Roche et al., 2015). Daily group allocation was then calculated by multiplying the area allocation by the number of cows remaining in the pre-calving group. Pre-calving grazing areas averaged $23( \pm 2.1 ; \mathrm{SD}), 31( \pm 4.0)$, and 40 $( \pm 4.4) \mathrm{m}^{2} /$ cow per $\mathrm{d}$ for Feed65, Feed90, and Feed120, respectively.

The 3 close-up treatment groups were grazed within the same paddock before calving and separated by an electric fence to control pasture allowance/treatment. Back-grazing beyond the day's allocation was prevented using electric fences and the cows had access to water in their respective treatment areas. Irrespective of allowance, close-up cows consumed a diet that was $75 \%$ fresh pasture and $25 \%$ pasture silage. The pasture offered pre-calving consisted of $65.1( \pm 17.33$; mean $\pm \mathrm{SD}) \%$ perennial ryegrass (Lolium perenne L.), 9.7 $( \pm 2.88) \%$ white clover (Trifolium repens), $9.0( \pm 7.86) \%$ weeds and other grasses (Dactylus glomerata, Holcus lanatus, and some Poa species), and 16.1 ( \pm 19.52$) \%$ dead material on a DM basis. Nutrient composition of feeds offered was determined by wet chemistry methods (Cumberland Valley Analytical Services, Hagerstown, MD) and is presented in Table 1.

As cows were grazed within the same paddock, pregrazing pasture height and mass did not differ between treatments. Pre-grazing pasture height was $9.1 \pm 1.7$ $\mathrm{cm}$ (mean $\pm \mathrm{SD} ; 9.0 \pm 1.67,9.1 \pm 1.76$, and $9.2 \pm$ $1.99 \mathrm{~cm}$ for Feed65, Feed90, and Feed 120 treatment groups, respectively), whereas pre-grazing pasture mass averaged $2,374 \pm 385.8 \mathrm{~kg}$ of DM/ha $(2,384 \pm 191.4$, $2,412 \pm 293.1$, and $2,326 \pm 258.9 \mathrm{~kg}$ of DM for Feed65, Feed90, and Feed120 treatment groups, respectively). Postcalving, cows from all 6 treatments were grazed together as a single herd and were offered a diet of fresh grazed pasture and pasture silage as a supplementary feed. Pre-grazing pasture height and mass were $9.8 \pm$ $1.53 \mathrm{~cm}$ and $3,062 \pm 411.9 \mathrm{~kg}$ of $\mathrm{DM} / \mathrm{ha}($ mean $\pm \mathrm{SD})$, respectively. The pasture consisted of $86.2( \pm 8.07) \%$ perennial ryegrass (Lolium perenne L.), $8.0( \pm 5.83) \%$ 


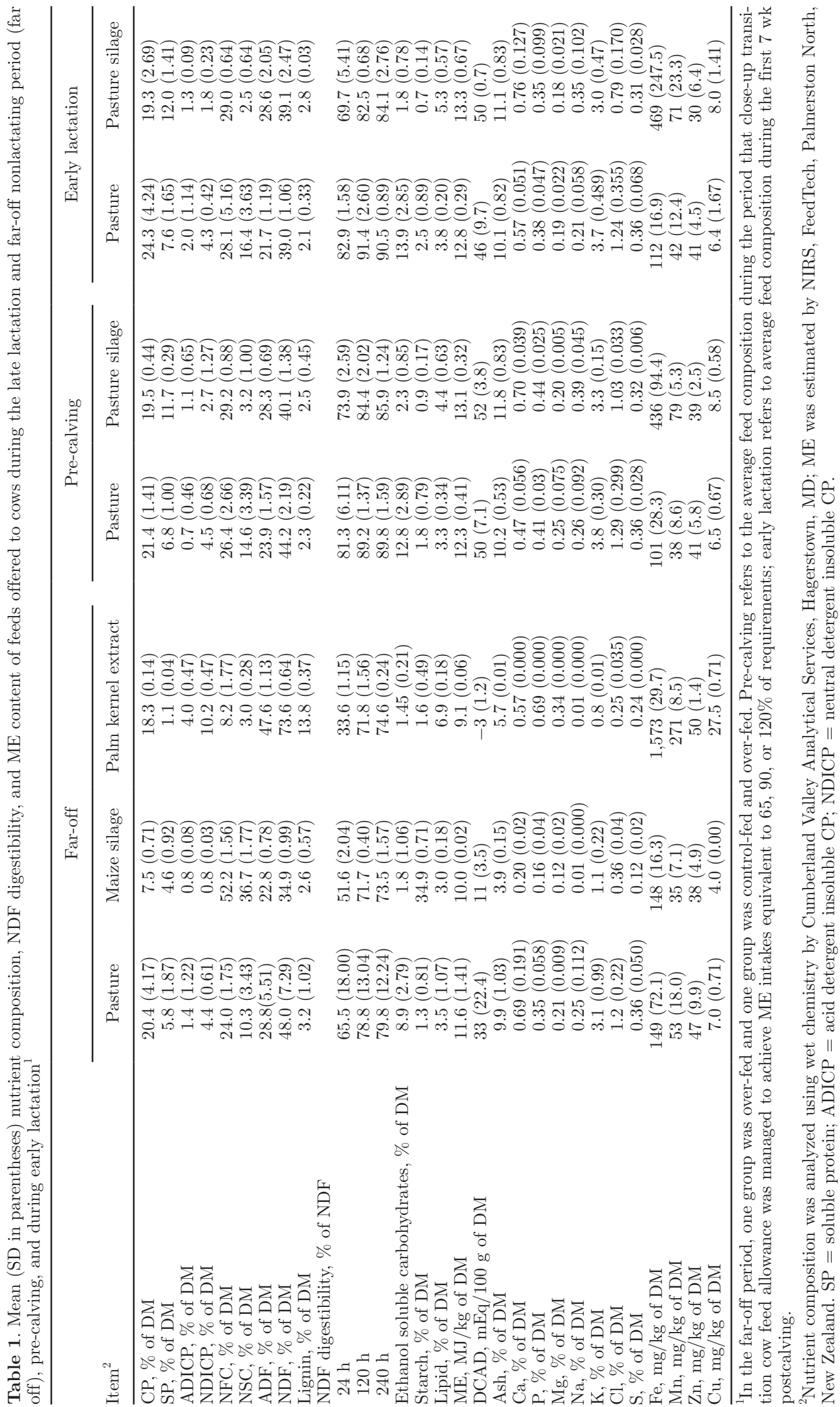


Table 2. Estimated composition, NDF digestibility, and ME content of the complete diet offered to cows during the late lactation and far-off nonlactating period (far off), pre-calving, and during early lactation ${ }^{1}$

\begin{tabular}{|c|c|c|c|c|}
\hline \multirow[b]{2}{*}{ Item $^{2}$} & \multicolumn{2}{|c|}{ Far-off } & \multirow[b]{2}{*}{ Pre-calving } & \multirow[b]{2}{*}{ Lactating } \\
\hline & Control-fed & Over-fed & & \\
\hline$\overline{\mathrm{CP}, \% \text { of } \mathrm{DM}}$ & 19.7 & 18.9 & 20.9 & 23.0 \\
\hline SP. $\%$ of DM & 7.7 & 6.3 & 8.0 & 8.7 \\
\hline $\mathrm{ADICP}, \%$ of $\mathrm{DM}$ & 1.7 & 1.5 & 0.8 & 1.8 \\
\hline NDICP, $\%$ of DM & 4.5 & 4.1 & 4.1 & 3.7 \\
\hline NFC, $\%$ of DM & 23.9 & 26.6 & 27.1 & 28.3 \\
\hline NSC, $\%$ of DM & 6.0 & 11.3 & 11.8 & 13.0 \\
\hline $\mathrm{ADF}, \%$ of $\mathrm{DM}$ & 31.4 & 29.3 & 25.0 & 23.4 \\
\hline $\mathrm{NDF}, \%$ of DM & 48.3 & 47.0 & 43.2 & 39.0 \\
\hline Lignin, $\%$ of DM & 4.5 & 3.7 & 2.3 & 2.2 \\
\hline \multicolumn{5}{|l|}{ NDF digestibility, \% of NDF } \\
\hline $24 \mathrm{~h}$ & 64.5 & 63.4 & 79.5 & 79.6 \\
\hline $120 \mathrm{~h}$ & 80.3 & 78.6 & 88.0 & 89.2 \\
\hline $240 \mathrm{~h}$ & 81.8 & 79.8 & 88.9 & 88.9 \\
\hline Ethanol soluble carbohydrates, \% of DM & 4.8 & 6.7 & 10.2 & 10.9 \\
\hline Starch, \% of DM & 1.2 & 4.6 & 1.6 & 2.1 \\
\hline Lipid, \% of DM & 4.4 & 3.8 & 3.6 & 4.2 \\
\hline $\mathrm{ME}, \mathrm{MJ} / \mathrm{kg}$ of $\mathrm{DM}$ & 11.9 & 11.5 & 12.5 & 12.9 \\
\hline $\mathrm{DCAD}, \mathrm{mEq} / 100 \mathrm{~g}$ of $\mathrm{DM}$ & 36 & 32 & 51 & 47 \\
\hline Ash, $\%$ of DM & 10.1 & 9.4 & 10.6 & 10.3 \\
\hline $\mathrm{Ca}, \%$ of DM & 0.68 & 0.64 & 0.52 & 0.62 \\
\hline $\mathrm{P}, \%$ of $\mathrm{DM}$ & 0.44 & 0.37 & 0.41 & 0.38 \\
\hline $\mathrm{Mg}, \%$ of $\mathrm{DM}$ & 0.23 & 0.21 & 0.24 & 0.19 \\
\hline $\mathrm{K} . \%$ of DM & 2.81 & 2.76 & 3.69 & 3.51 \\
\hline $\mathrm{S}, \%$ of $\mathrm{DM}$ & 0.32 & 0.32 & 0.35 & 0.35 \\
\hline $\mathrm{Na}, \%$ of $\mathrm{DM}$ & 0.28 & 0.23 & 0.29 & 0.25 \\
\hline $\mathrm{Cl}, \%$ of $\mathrm{DM}$ & 0.98 & 1.03 & 1.22 & 1.13 \\
\hline $\mathrm{Fe}, \mathrm{mg} / \mathrm{kg}$ of $\mathrm{DM}$ & 491.3 & 286.8 & 183.3 & 199.7 \\
\hline $\mathrm{Mn}, \mathrm{mg} / \mathrm{kg}$ of DM & 97.1 & 69.3 & 47.8 & 48.9 \\
\hline $\mathrm{Zn}, \mathrm{mg} / \mathrm{kg}$ of $\mathrm{DM}$ & 43.6 & 44.7 & 40.4 & 38.5 \\
\hline $\mathrm{Cu}, \mathrm{mg} / \mathrm{kg}$ of $\mathrm{DM}$ & 10.7 & 8.3 & 7.0 & 6.8 \\
\hline
\end{tabular}

${ }^{1}$ Control-fed and over-fed refer to the far-off feeding level treatments imposed. Pre-calving refers to the average feed composition during the period that close-up transition cow feed allowance was managed to achieve ME intakes equivalent to 65,90 , or $120 \%$ of requirements; early lactation refers to average feed composition during the first $7 \mathrm{wk}$ postcalving.

${ }^{2}$ Estimated composition of the diet was calculated from the measured composition of the feed ingredients and the average intake of the feed ingredients over the period reported. SP $=$ soluble protein; ADICP $=$ acid detergent insoluble CP; NDICP = neutral detergent insoluble CP. Nutrient composition was analyzed using wet chemistry by Cumberland Valley Analytical Services, Hagerstown, MD; ME was estimated by NIRS, FeedTech, Palmerston North, New Zealand.

white clover (Trifolium repens), $4.7( \pm 5.10) \%$ weeds and other grasses (Dactylus glomerata, Holcus lanatus, and some Poa species), and 1.1 ( \pm 1.20$) \%$ dead material on a DM basis. Pasture silage allowance was determined by the estimated pasture DMI to achieve a $85: 15 \%$ fresh pasture:pasture silage ration. The nutritive characteristics of the feed ingredients and the rations fed during the BCS set-up phase, the close-up period, and to cows in early lactation are presented in Tables 1 and 2.

\section{Milk, DMI, BCS, and BW}

Cows were milked twice daily and milk yield was determined daily from wk 2 to 7 (30-unit rotary; GEA Surge, Dusseldorf, Germany). Milk was sampled twice weekly on consecutive afternoon and morning milkings and a composite sample analyzed for milk composition by infrared analysis (FT120, Foss Electric, Hillerød, Denmark) and SCC using an electronic fluorometric cell-counting technique (Fossomatic, Foss Electric). Dry matter intake was estimated as the difference between pre- and postgrazing mass $\left(\mathrm{kg}\right.$ of $\left.\mathrm{DM} / \mathrm{m}^{2}\right)$ multiplied by the area allocated/cow $\left(\mathrm{m}^{2}\right)$. Pasture mass was determined pre- and postgrazing with a rising plate meter (Farmworks, Palmerston North, New Zealand) using methodology described by Roche et al. (2005). Group pasture DMI was calculated as the product of the difference between the pre- and postgrazing pasture mass and area grazed, as outlined by Roche et al. (2005). Silage offered was weighed pre-feeding, providing an estimate of group DMI. Average cow DMI was calculated by dividing group daily DMI by the number of cows. 
Weekly, following the morning milking or at approximately $0800 \mathrm{~h}$ during the nonlactating period, BW was recorded and BCS was determined by a minimum of 3 experienced assessors (BCS was assessed on a 1-10-point scale, where 1 is emaciated and 10 obese; Roche et al., 2004). All BCS assessors were trained and recalibrated at the start of the experiment following the procedures set out in Macdonald and Roche (2004).

\section{Blood Sampling and Analyses}

Blood was sampled by coccygeal venipuncture weekly for $4 \mathrm{wk}$ before and $5 \mathrm{wk}$ after calving and on $\mathrm{d} 0$, $1,2,3$, and 4 relative to calving. Blood was collected in evacuated blood tubes containing a lithium heparin anti-coagulant (Becton Dickinson Vacutainer Systems, Franklin Lakes, NJ); samples were placed immediately into iced water and centrifuged within $30 \mathrm{~min}$ at 1,500 $\times g$ for $12 \mathrm{~min}$ at $4^{\circ} \mathrm{C}$. Following centrifugation, aspirated plasma was stored at $-20^{\circ} \mathrm{C}$ until assayed.

Blood metabolite assays were performed by Gribbles Veterinary Pathology Ltd. (Hamilton, New Zealand). Blood metabolites were assayed using colorimetric techniques at $37^{\circ} \mathrm{C}$ with a Hitachi Modular P800 analyzer (Roche Diagnostics, Indianapolis, IN). Roche reagent kits were used to measure plasma concentrations of albumin $(\mathrm{g} / \mathrm{L}$; bromocresol green reaction at $\mathrm{pH} 4.1)$, $\mathrm{BHB}$ (mmol/L; reduction of NAD to NADH during oxidation of D-3-hydroxybutyrate to acetoacetate), Ca (mmol/L; $\sigma$-cresolphthalein complexone method), $\mathrm{Mg}$ (mmol/L; xylidyl blue reaction), and total protein $(\mathrm{g} / \mathrm{L}$; biuret method). Plasma globulin was calculated as the difference between total protein and albumin. Plasma fatty acid concentrations $(\mathrm{mmol} / \mathrm{L})$ were measured using Wako Chemicals (Osaka, Japan) kit fatty acid HR2 measuring oxidative condensation of 3-methyl-Nethyl-N- $\beta$ hydroxyethyl aniline with 4 -aminoantipyrine. The inter- and intra-assay coefficients of variation for assays were between 0.8 and $5.3 \%$, and 0.5 and $15 \%$, respectively.

Plasma Il-1ß, IL-6, haptoglobin (Hp), cholesterol, total antioxidant capacity (TAC), and reactive oxygen species (ROS) were measured on blood samples collected on d 3, wk 1, and wk 4 postcalving. Plasma concentrations of IL-1 $(\mu \mathrm{g} / \mathrm{L}$; Pierce, Thermo Scientific, Rockford, IL), IL-6 ( $\mu \mathrm{g} / \mathrm{L}$; GenWay Biotech Inc., San Diego, CA), and Hp (Life Diagnostics Inc., West Chester, PA) were analyzed using commercially available bovine ELISA kits. Cholesterol (Cayman Chemical Company, East Ann Arbor, MI), TAC (Cayman Chemical Company), and ROS (Cell Biolabs Inc., San Diego, CA) were analyzed using commercially available fluorimetric kits. For IL-1 $\beta$, IL-6, Hp, cholesterol, TAC, and ROS, respectively, the intra-assay CV was 4, 7, 3,
4,7 , and $5 \%$, and the inter-assay $\mathrm{CV}$ was $9,14,6,12$, 5 , and $3 \%$.

\section{Statistical Analysis}

Statistical analyses were performed using SAS 9.3 (SAS Institute Inc., Cary, NC) and significance was declared if $P \leq 0.05$. We tested unstructured and compound symmetry covariance structures for all models and used the one with the lowest Akaike's information criterion value.

Milk, BW, and BCS Data. Average weekly production for each cow was calculated for wk 2 to 7 and analyzed using a mixed models approach to repeated measures ANOVA (PROC MIXED, SAS 9.3), with late lactation and far-off feeding level strategy (i.e., far-off_control-fed or far-off_over-fed), close-up feeding level strategy (i.e., Feed65, Feed90, and Feed120), week, and their interactions as fixed effects and cow as the random effect. Production from the first $2 \mathrm{wk}$ in February, before start of treatments, was included as a covariate in all analyses.

Body weight and BCS data were divided into 3 periods (i.e., weekly pre-calving from February to May, weekly (relative to calving) pre-calving from wk 4 to 1 , and weekly (relative to calving) postcalving from wk 2 to 7) and each period analyzed separately. Data were subjected to repeated measures ANOVA using mixed models. Statistical models included BW and BCS from the first 2 wk in February before the start of treatments as covariate; late lactation and far-off feeding level strategy, close-up feeding level strategy, time, and their interactions as fixed effects; and cow as the random effect.

Blood Data. Blood data were divided into 3 periods (i.e., weekly pre-calving, daily postcalving from d 0 to 4 , and weekly postcalving) and each period analyzed separately. Data were subjected to repeated measures ANOVA using mixed models. Statistical models included late lactation and far-off feeding level strategy, close-up feeding level strategy, and their interactions as fixed effects, and cow as the random effect. Covariates included calving date within the herd (difference between actual calving date and the earliest calving date, d), and length of treatment period [difference (in d) between start of close-up feeding level treatment and actual calving date]. Data were $\log _{10}$ transformed if required to achieve homogeneity of variance. For blood $\mathrm{BHB}$ and $\mathrm{Ca}$, the percentage of samples with low $(\mathrm{BHB}<1.2 \mathrm{mmol} / \mathrm{L} ; \mathrm{Ca}<1.4 \mathrm{mmol} / \mathrm{L})$, medium $(1.2$ $<\mathrm{BHB}<2.0 \mathrm{mmol} / \mathrm{L} ; 1.4<\mathrm{Ca}<2.0 \mathrm{mmol} / \mathrm{L})$, and high $(\mathrm{BHB}>2.0 \mathrm{mmol} / \mathrm{L}$; $\mathrm{Ca}>2.0 \mathrm{mmol} / \mathrm{L})$ concentrations were subjected to chi-squared test of association (PROC FREQ, SAS 9.3). 


\section{RESULTS}

\section{Dry Matter Intake}

As intended, the different area allowances/cow during the close-up (i.e., transition) period resulted in differences in DMI. Cows in the Feed65, Feed90, and Feed120 treatments consumed an estimated $4.9( \pm 0.6$; $\mathrm{SD}), 6.6( \pm 1.1)$, and $8.0( \pm 1.3) \mathrm{kg}$ of pasture $\mathrm{DM} / \mathrm{d}$ and $1.6( \pm 0.1), 2.1( \pm 0.1)$, and $2.6( \pm 0.1) \mathrm{kg}$ of pasture silage $\mathrm{DM} / \mathrm{d}$ during the $19 \pm 5.4 \mathrm{~d}$ before calving. This equated to a total DMI of $6.4( \pm 0.6$; SD $), 8.7( \pm 1.1)$, and $10.6( \pm 1.3) \mathrm{kg}$ of $\mathrm{DM} / \mathrm{d}$ and a ME intake of 80 $( \pm 7.6), 109( \pm 14.0)$, and $132( \pm 16.5) \mathrm{MJ}$ of $\mathrm{ME} / \mathrm{d}$; this is equivalent to approximately 65,90 , and $110 \%$ of estimated ME requirements based on cow BW before calving (Roche et al., 2005). On average, during the first 35 DIM postcalving, cows consumed $14.5( \pm 3.0)$ $\mathrm{kg}$ of $\mathrm{DM}$, of which $83 \%$ was fresh pasture and $17 \%$ was pasture silage. This equated to a ME intake of 183 $( \pm 39.2) \mathrm{MJ} / \mathrm{d}$ postcalving.

\section{Milk Production, BCS, and BW}

The profiles of BCS and BW gain during the far-off nonlactating period are presented in Figure 1. At the end of the lactation, cows in the far-off_control-fed gain group were 0.7 BCS units fatter (10-point BCS scale; Roche et al., 2004) and $30 \mathrm{~kg}$ heavier than cows in the far-off_over-fed group. During the following $5 \mathrm{wk}$, cows in the far-off_over-fed group gained 0.5 BCS units more than the far-off_control-fed group, and were 0.2 BCS units thinner (10-point scale; $P<0.001) 1$ mo pre-calving (i.e., equivalent to $\sim 0.06 \mathrm{BCS}$ units thinner in the 5-point scale; Roche et al., 2004).

The effects of far-off and close-up feeding strategies on milk production during the first 7 wk are presented in Figure 2 and Table 3 and effects on BCS and BW pre- and postcalving are presented in Figure 3. There was no interaction between the feeding strategies, so main effects are presented. There was no effect of faroff nutrition strategy on any of the milk production variables considered $(P \geq 0.48)$. However, BCS loss postcalving was greater in the far-off_control-fed cows; 1 wk pre-calving, far-off_control-fed cows were 0.2 BCS units fatter $(P<0.001)$ than cows in the far-off_overfed group; by 2 wk postcalving, the difference was 0.1 BCS units $(P<0.05)$ and the difference diminished to less than 0.1 BCS units by 7 wk postcalving $(P=0.11)$.

Close-up feeding strategy affected BCS loss postcalving. All 3 groups were the same BCS 4 wk pre-calving, but by 1 wk pre-calving, cows on the Feed65 of ME requirements diet were $0.25 \mathrm{BCS}$ units thinner $(P<$ 0.001) than cows in the other 2 groups. This difference declined postcalving and by 4 wk postcalving there was no difference between the treatments. These changes are mirrored in BW, with a 22 to $28 \mathrm{~kg}$ difference in BW 1 wk pre-calving $(P<0.001)$ shrinking to $10 \mathrm{~kg}(P$ $<0.05) 5$ wk postcalving. A tendency $(P<0.10)$ was observed for milk production to be affected by close-up feeding strategy. During wk 2 postcalving, cows that were allocated $65 \%$ of their ME requirements during the close-up period produced less $(P<0.05)$ milk, fat, protein, and lactose than cows in the other 2 feed allowance categories, which did not differ from each other. There was an interaction $(P<0.05)$ between far-off and close-up feeding strategies in average milk $\mathrm{CP} \%$, with far-off_control-fed-Feed65, far-off_control-fed-Feed90, far-off_control-fed-Feed120, far-off_over-fed-Feed65, far-off_over-fed-Feed90, and far-off_over-fed-Feed120 cows producing milk with $3.51,3.57,3.62,3.59,3.58$, and $3.52 \%$, respectively. Considering the lack of interaction in milk CP yield, this difference was not deemed to be of biological relevance.
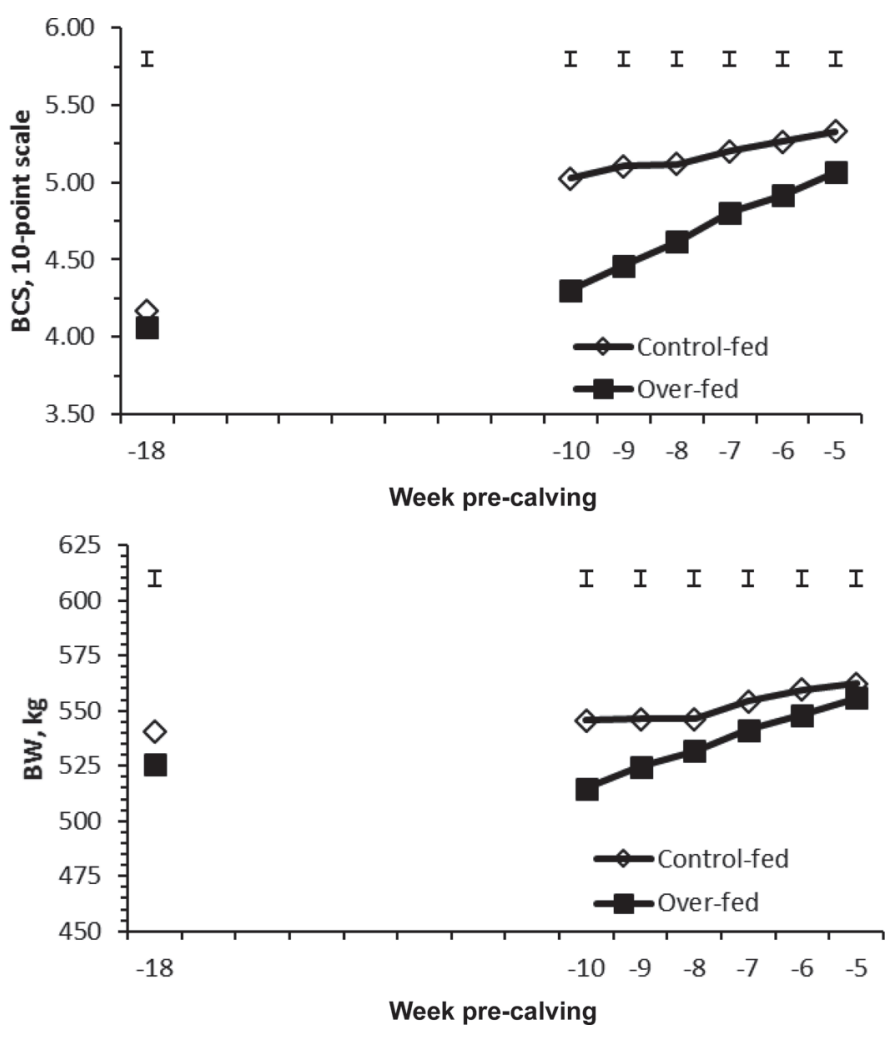

Figure 1. Effect of late lactation and far-off nonlactating cow feeding strategies on cow BCS. Feed allowance was managed during late lactation to create 2 different BCS groups at dry off. Subsequently, cows were either control-fed or over-fed during the far-off nonlactating period to maintain or gain BCS, respectively, and achieve the same BCS pre-calving. All cows were dried off $79 \pm 9.5$ d before calving. Error bars represent $2 \times \mathrm{SE}$ of the difference. 

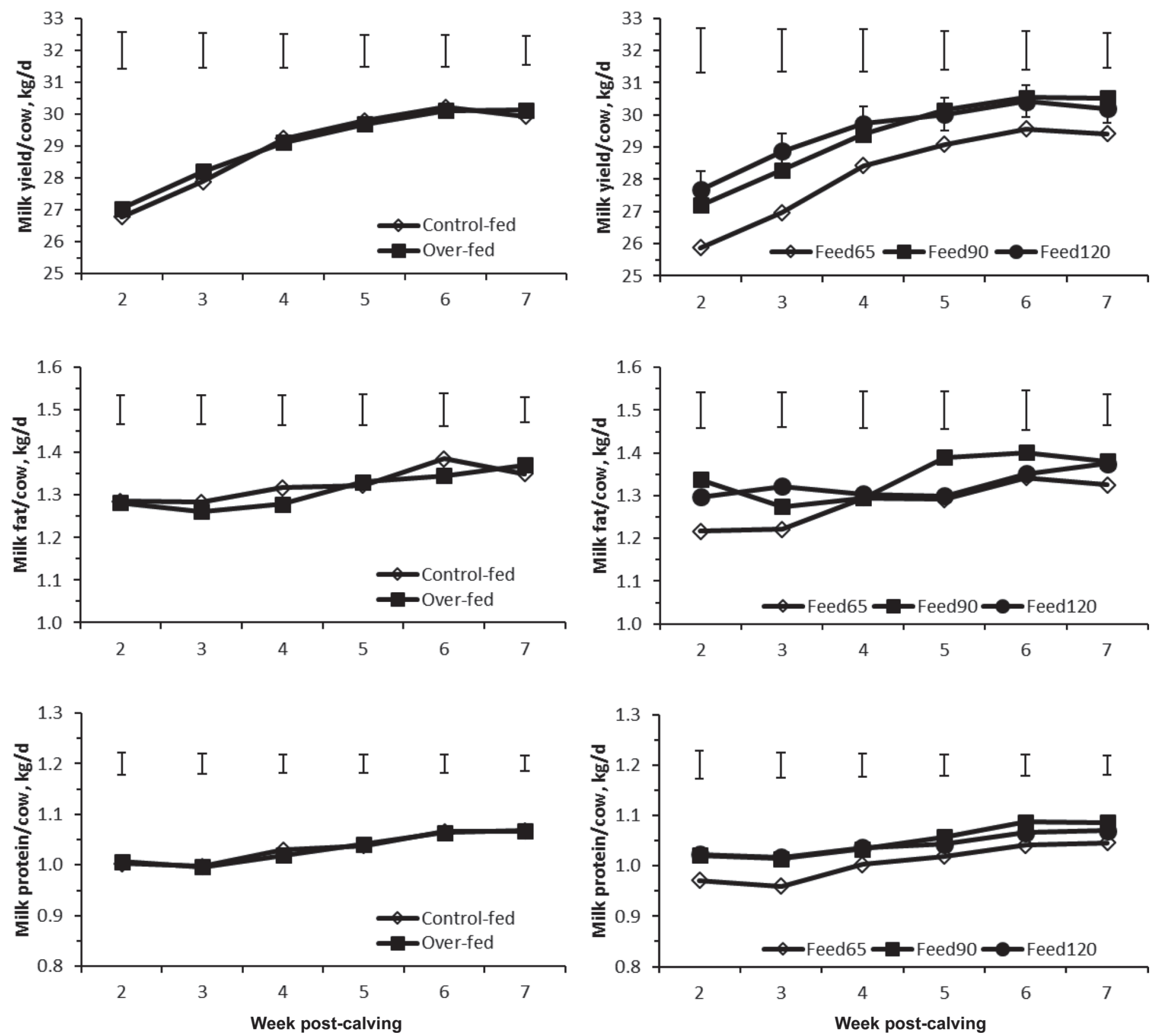

Figure 2. Effects of far-off and close-up feed allowance on milk production profiles during the first 7 wk postcalving. Feed allowance was managed during late lactation to create 2 different BCS groups at dry off. Subsequently, cows were either control-fed or over-fed during the far-off nonlactating period to maintain or gain BCS, respectively, and achieve the same BCS pre-calving. Each herd of cows was managed during the close-up transition period (i.e., $<4$ wk pre-calving) to achieve daily ME intakes during the 3 wk before calving (i.e., close-up period) equivalent to 65,90 , and $120 \%$ of their requirements (Feed65, Feed90, and Feed120, respectively; Roche et al., 2005). Error bars represent $2 \times$ SE of the difference.

\section{Indicators of Metabolic and Immune Function}

Blood fatty acid and BHB concentrations during the transition period were affected by both far-off and close-up feeding strategies (Figure 4), but no interaction was present. Cows in the far-off_control-fed treatment group had greater concentrations of fatty acids and BHB before and after calving $(P<0.01)$. Differ- ences in blood BHB concentrations were evident until 5 wk postcalving $(P<0.05)$, and there was a tendency $(P<0.10)$ for blood fatty acids to remain elevated also. Both fatty acid and BHB concentrations were greater pre-calving in the restricted close-up feed allowance group (Feed65), but BHB concentrations were less $(P=0.06)$ during the 5 wk postcalving that blood biochemistry was monitored. This was despite a lack of 


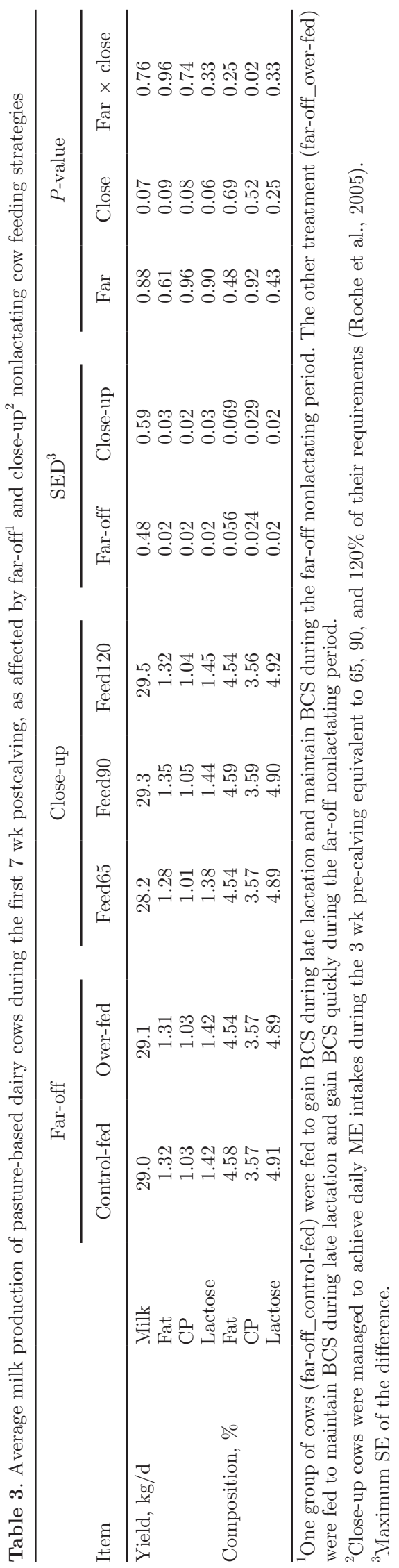

effect of close-up treatment on postcalving blood fatty acid concentrations.

Total blood protein concentration was not affected by either far-off or close-up feeding strategies (Figure $5)$. Cows in the far-off_over-fed group had a marginally greater (1.09 vs. $1.04 ; P<0.05)$ albumin to globulin ratio postcalving than the cows in the far-off_controlfed group because of a tendency $(P<0.10)$ for a higher blood albumin concentration $(0.6 \mathrm{~g} / \mathrm{L})$. In comparison, there was a strong effect of close-up feeding level on the composition of the blood protein pool, with the albumin to globulin ratio lower $(P<0.001)$ in the Feed65 treatment compared with the other 2 treatments, which did not differ from each other. This effect of treatment is due, in particular, to a lower $(P<0.001)$ blood albumin concentration $(36.3,38.0$, and $38.2 \mathrm{~g} / \mathrm{L}$ for the Feed65, Feed90, and Feed120 pre-calving feeding level treatments, respectively) and a tendency $(P<0.10)$ for greater blood globulin concentrations in this group. The differences in blood albumin concentration and in the albumin to globulin ratio remained until $5 \mathrm{wk}$ in milk, when blood biochemistry measurements ceased.

The liver enzymes AST and GDH were also affected by far-off and close-up nonlactating cow feeding strategy (Figure 6). Cows in the far-off_over-fed group had elevated concentrations of AST wk 1 and 2 pre-calving, but no evident effect postcalving; GDH concentrations were not affected by the far-off nonlactating cow diet. Cows in the Feed65 treatment had lower blood concentrations of AST $(P=0.06)$ and GDH $(P<0.05)$ during the $4 \mathrm{~d}$ immediately following calving, but the effect of treatment did not extend further into lactation.

Far-off nonlactating cow feeding strategy did not affect the plasma variables considered indicative of peripartum inflammatory state (IL-1 $\beta$, IL-6, TAC, ROS, $\mathrm{Hp}$, or cholesterol; Figures 7 and 8, respectively), except for a higher $(P<0.05)$ concentration of cholesterol in blood on $\mathrm{d} 7$ postcalving in the far-off_control-fed cows (BCS group $\times$ time interaction: $P=0.08$ ). There was an interaction $(P<0.05)$ between close-up feeding strategy and time postcalving in plasma $\mathrm{Hp}$ and cholesterol concentrations. Haptoglobin concentration was 3 - to 7 -fold greater $(P<0.05)$ in the Feed65 treatment on $\mathrm{d} 3$ postcalving than the cows in the Feed90 and Feed120 treatments, respectively, but there was no effect of treatment at subsequent measurements. In comparison, blood cholesterol concentration was 34 and $44 \%$ lower in the Feed65 treatment than cows in the 90 and $120 \%$ categories, respectively.

Blood $\mathrm{Ca}$ and $\mathrm{Mg}$ concentrations were not affected by far-off nonlactating cow nutrition strategy, but blood Ca declined linearly $(P<0.05)$ on the day of calving with greater feed allocation to the close-up transition cow (Figure 9). On the day of calving, 48, 
70 , and $80 \%$ of cows had blood Ca concentrations $<2.0$ mmol/L (i.e., hypocalcemic; $P<0.05$ ) and 6,16 , and $20 \%$ of cows had blood calcium concentrations $<1.4$ $\mathrm{mmol} / \mathrm{L}$ (i.e., clinically hypocalcemic; $P<0.05$ ) in the Feed65, Feed90, and Feed120 treatments, respectively. Blood Mg concentration postcalving was not affected by either far-off or close-up feeding strategy.

\section{DISCUSSION}

We hypothesized that excessive energy consumption does not have a detrimental effect during the far-off nonlactating period, when cows have a BCS of 5.0 at calving (10-point scale; Roche et al., 2004). The data generated indicate that the far-off nonlactating period feeding level did not affect postcalving milk production and, although statistically significant $(P<0.05)$, had only very small biological effects on the cows' metabolic profile after calving. Furthermore, the direction of the treatment effect indicates that cows that were over-fed during the far-off nonlactating period were in a superior metabolic state compared with those fed to requirements. We also hypothesized that restricting cows to $65 \%$ of $\mathrm{ME}$ requirements during the $3 \mathrm{wk}$ before calving would have negative effects on health and productivity. In both production measures and plasma variables chosen to represent peripartum metabolic and inflammatory state, Feed65 cows produced less milk and had an inferior metabolic and inflammatory state when compared with Feed90 and Feed120 cows. These results support the hypothesis that a threshold level of close-up restriction exists, below which the cow is negatively affected. Nevertheless, as in previous studies (Roche et al., 2005, 2015; Roche, 2007), increased DMI before calving resulted in lower blood Ca concentration on the day of calving and a greater proportion of clinically and subclinically hypocalcemic cows.

A limitation of undertaking grazing experiments is an inability to quantify DM and ME intake with sufficient accuracy to quantify energy balance. Measuring DMI is inherently difficult with grazing dairy cows and cannot be achieved with the degree of accuracy of stall-fed animals. As in this experiment, DMI in grazing studies is generally estimated from differences between
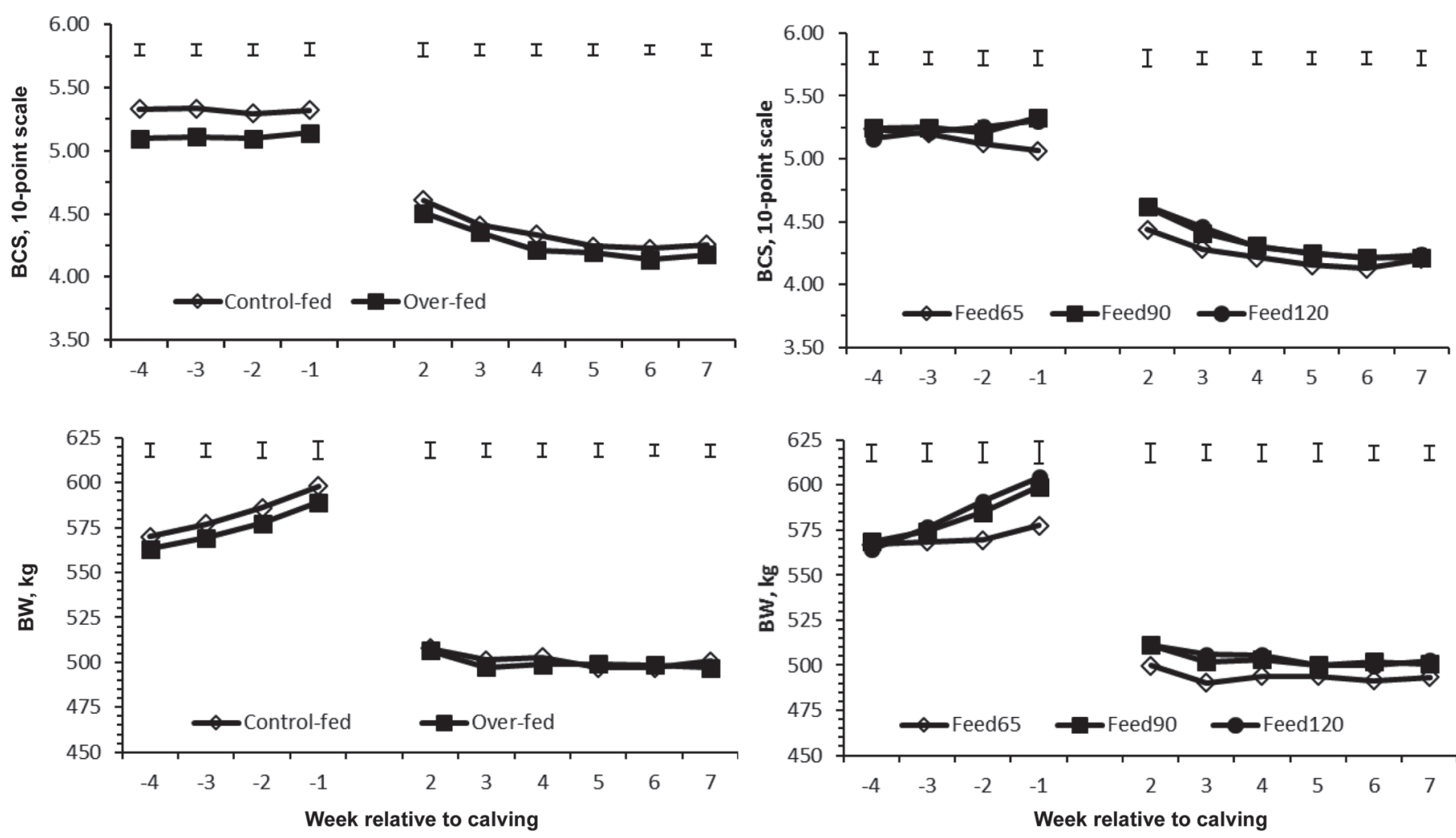

Figure 3. Effects of far-off and close-up feed allowance on BCS and BW profiles during the transition period and out to 7 wk postcalving. Feed allowance was managed during late lactation to create 2 different BCS groups at dry off. Subsequently, cows were either control-fed or over-fed during the far-off nonlactating period to maintain or gain BCS, respectively, and achieve the same BCS pre-calving. Each herd of cows was managed during the close-up transition period (i.e., $<4$ wk precalving) to achieve daily ME intakes during the 3 weeks before calving (i.e., close-up period) equivalent to 65, 90, and $120 \%$ of their requirements (Feed65, Feed90, and Feed120, respectively; Roche et al., 2005). Error bars represent $2 \times \mathrm{SE}$ of the difference. 
pasture and supplementary feed offered and refused at a herd level. Discussions around energy balance and feeding level are, therefore, based on changes to BCS and metabolic indicators of energy balance (e.g., fatty acids); however, the discussions and conclusions are no less relevant as a result.

We can, however, use the cow's pre-calving plasma fatty acid concentration to support the discussion around BCS change and help determine the level of restriction to which the cows were subjected. Roche et al. (2005) presented a pre-calving feeding level response study that allowed the deduction of the fatty acid response curve to a feed restriction. They were able to define a BCS and BW change consistent with a zero energy balance in grazing dairy cows. This allowed the use of the presented fatty acid profile to predict the cow's ME intake as a proportion of requirements:

$$
\begin{gathered}
\text { ME intake, as } \% \text { ME requirements }= \\
-77.9(12.81) \text { fatty acids, mmol } / \mathrm{L}+124 \\
P<0.05 ; \mathrm{r}^{2}=0.92 . \text { (SE in parentheses) }
\end{gathered}
$$

Using this response curve, we estimate that the Feed65 close-up cows in the current study, on average, consumed $\sim 65 \%$ of their ME requirements daily, as intended. In comparison, the Feed90 and Feed120 groups
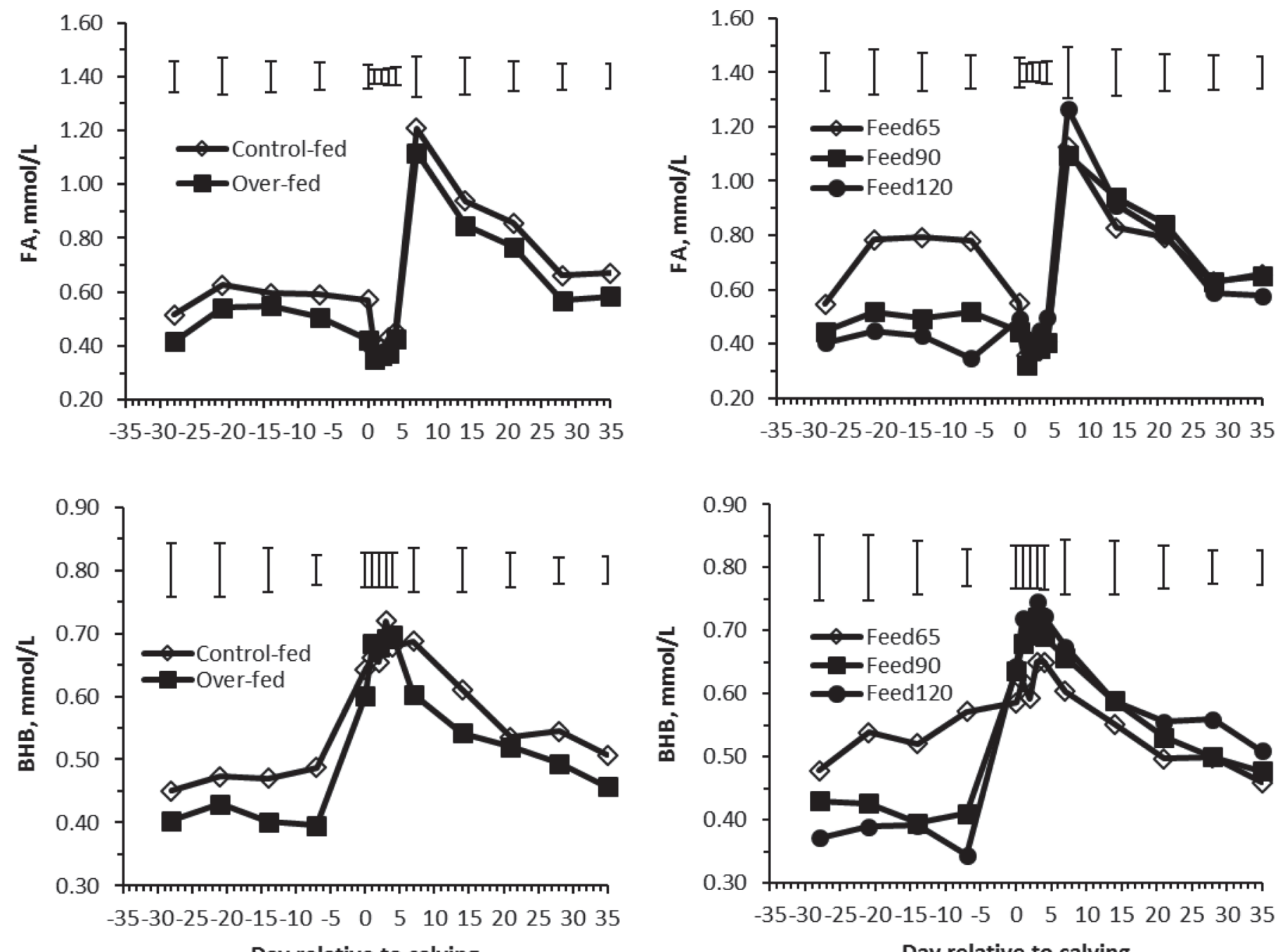

Day relative to calving

Figure 4. Effects of far-off and close-up feed allowance on fatty acid (FA) and BHB concentration during the transition period. Feed allowance was managed during late lactation to create 2 different BCS groups at dry off. Subsequently, cows were either control-fed or over-fed during the far-off nonlactating period to maintain or gain BCS, respectively, and achieve the same BCS pre-calving. Each herd of cows was managed during the close-up transition period (i.e., $<4$ wk pre-calving) to achieve daily ME intakes during the 3 wk before calving (i.e., close-up period) equivalent to 65, 90, and $120 \%$ of their requirements (Feed65, Feed90, and Feed120, respectively; Roche et al., 2005). Error bars represent $2 \times$ SE of the difference. 

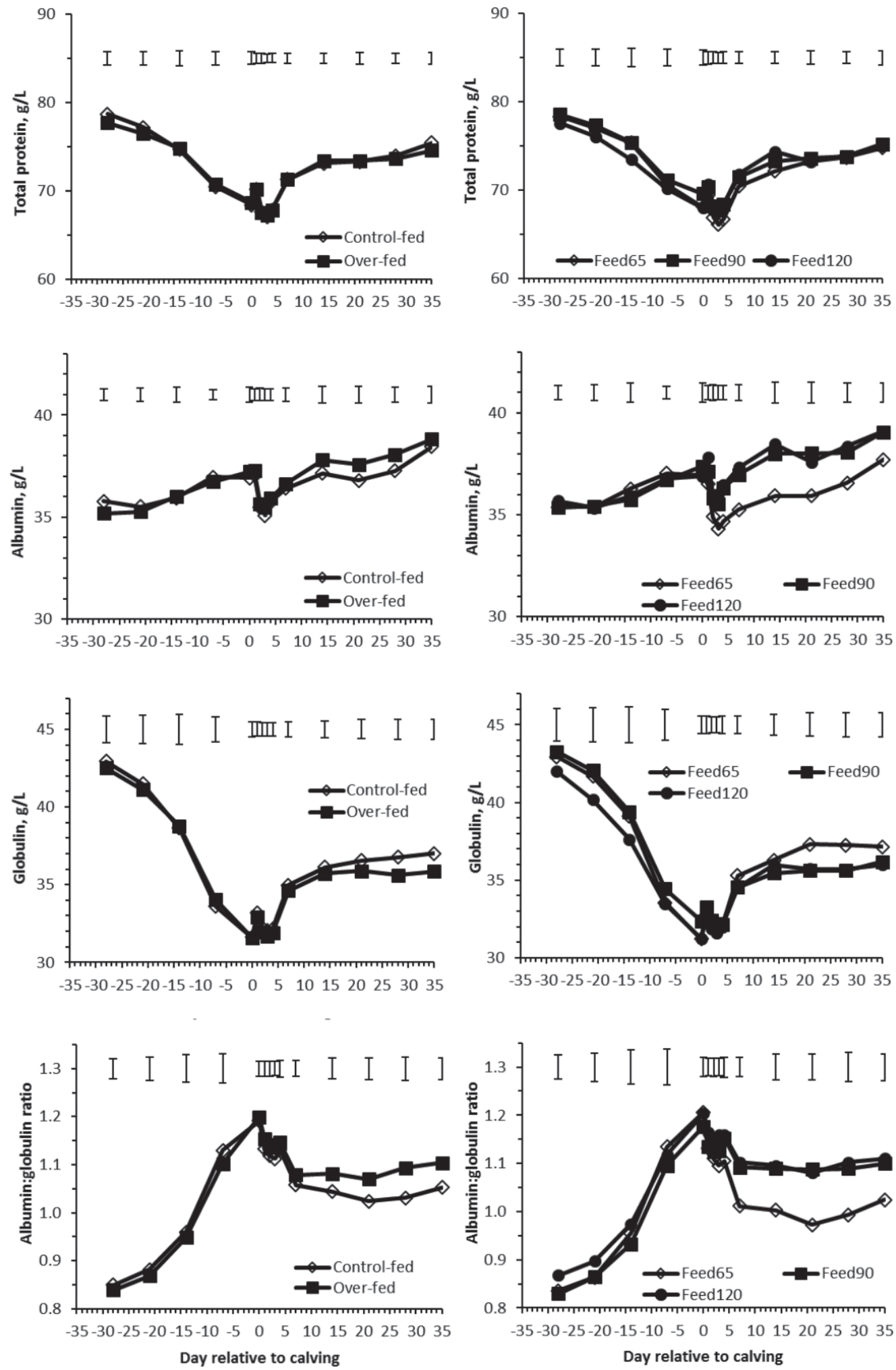

Figure 5. Effects of far-off and close-up feed allowance on blood protein concentration during the transition period. Feed allowance was managed during late lactation to create 2 different BCS groups at dry off. Subsequently, cows were either control-fed or over-fed during the far-off nonlactating period to maintain or gain BCS, respectively, and achieve the same BCS pre-calving. Each herd of cows was managed during the close-up transition period (i.e., $<4$ wk pre-calving) to achieve daily ME intakes during the $3 \mathrm{wk}$ before calving (i.e., close-up period) equivalent to 65,90 , and $120 \%$ of their requirements (Feed65, Feed90, and Feed120, respectively; Roche et al., 2005). Error bars represent $2 \times$ SE of the difference. 

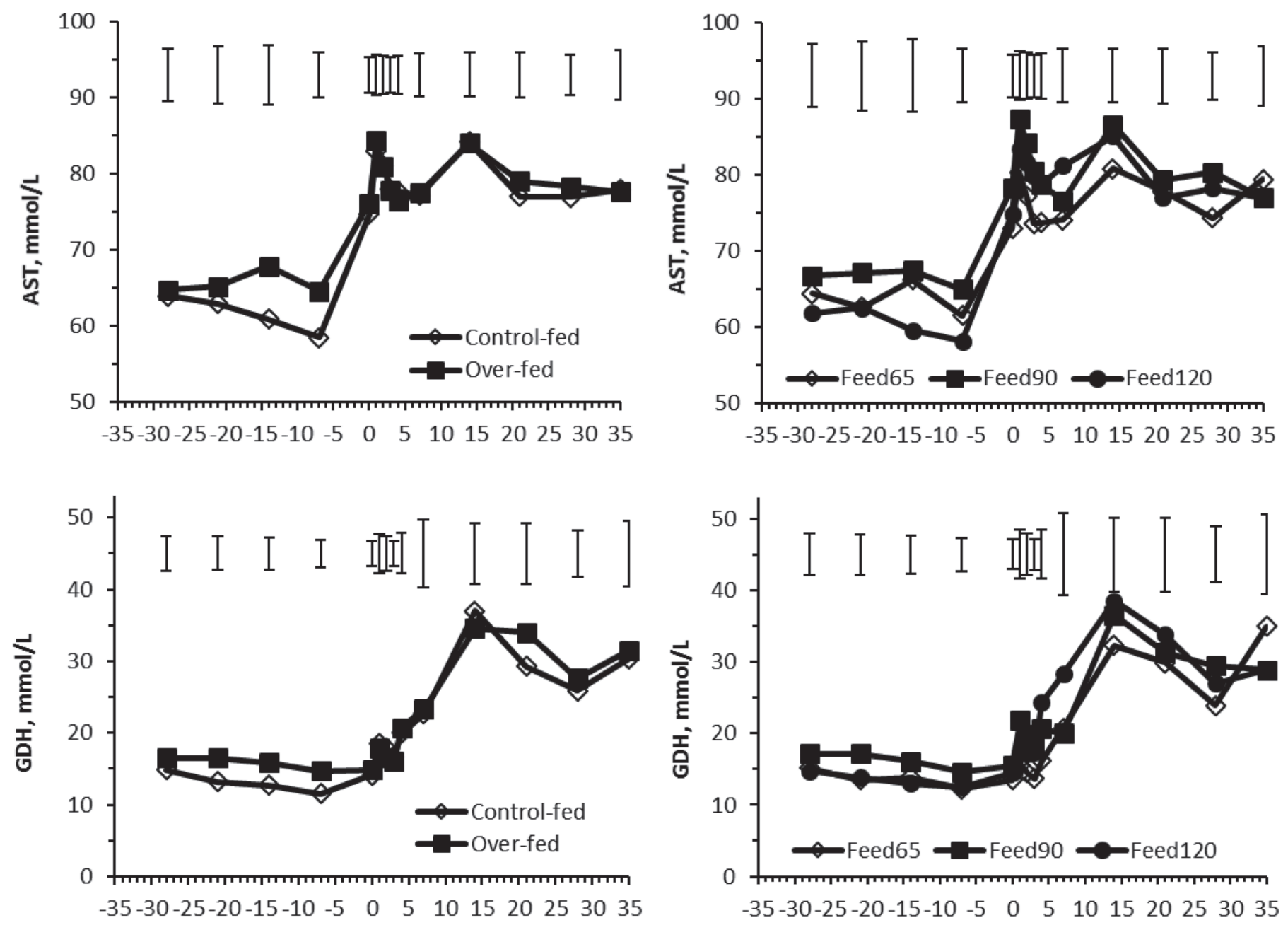

Day relative to calving

Day relative to calving

Figure 6. Effects of far-off and close-up feed allowance on the concentration of aspartate amino transferase (AST) and glutamate dehydrogenase $(\mathrm{GDH})$ during the transition period. Feed allowance was managed during late lactation to create 2 different BCS groups at dry off. Subsequently, cows were either control-fed or over-fed during the far-off nonlactating period to maintain or gain BCS, respectively, and achieve the same BCS pre-calving. Each herd of cows was managed during the close-up transition period (i.e., $<4$ wk pre-calving) to achieve daily ME intakes during the 3 wk before calving (i.e., close-up period) equivalent to 65, 90, and 120\% of their requirements (Feed65, Feed90, and Feed120, respectively; Roche et al., 2005). Error bars represent $2 \times \mathrm{SE}$ of the difference.

consumed $\sim 85$ and $100 \%$ of their ME requirements; this is compared with the estimated ME intakes of 90 and $110 \%$ of requirements from pre- and postgrazing pasture measurements, suggesting a reasonable accuracy of prediction. Using the same equation on the fatty acid data presented by Roche et al. (2015), the results predicted $\mathrm{ME}$ intakes equivalent to $\sim 80 \% \mathrm{ME}$ requirements, when the estimated DMI and ME content of the feeds indicated that cows consumed $75 \%$ of ME requirements. Other metabolites associated with energy balance, such as BHB, did not provide a robust predictive equation. These results give some confidence that blood fatty acids from a subset of cows pre-calving could be used to predict the adequacy of ME intake relative to requirements and could be useful, should a cow-side test for blood fatty acids be developed in the future.

\section{Far-Off Nonlactating Period Nutrition and Postcalving Metabolic State}

The profile of BCS change during the far-off nonlactating period (Figure 1) and the difference in the rate of BCS gain between the over-fed and control-fed treatments confirms that the feeding level strategies were effective. Far-off_over-fed cows gained BCS 2.5 
times faster than cows in the far-off_control-fed group, whose DMI was managed to ensure only a small positive energy balance during this time.

Over-feeding during the far-off period had little effect on the metabolic state of the transition dairy cow in the current study; although the direction of difference was positive, milk production was not affected by treatment. Cows in the far-off_over-fed group lost less BCS postcalving, had lower blood fatty acid and BHB concentrations in blood before and after calving, and had a higher albumin to globulin ratio after calving. The short-term greater blood cholesterol concentration (i.e., elevated on d 7 but not d 28) in the far-off_controlfed cows is also consistent with a greater net release of fatty acids early postcalving. Although the differ- ences measured between far-off dietary strategies were biologically small, within herd variation in fatty acids, $\mathrm{BHB}$, and albumin to globulin ratio before calving have been associated with increased risk of metabolic and infectious diseases in other studies (Dyk, 1995; Burke et al., 2010; Sheehy et al., 2014); for example, higher concentrations of fatty acids before calving have been linearly associated with a greater risk of postpartum disease (Dyk, 1995) and a lower albumin to globulin ratio pre-calving is a characteristic of cytological endometritis postcalving (Burke et al., 2010). With small numbers of cows/treatment $(\mathrm{n}=75)$, differences in disease incidence are unlikely to be detected. However, the metabolic profile presented indicates, at least, that over-fed, far-off nonlactating cows in this experiment
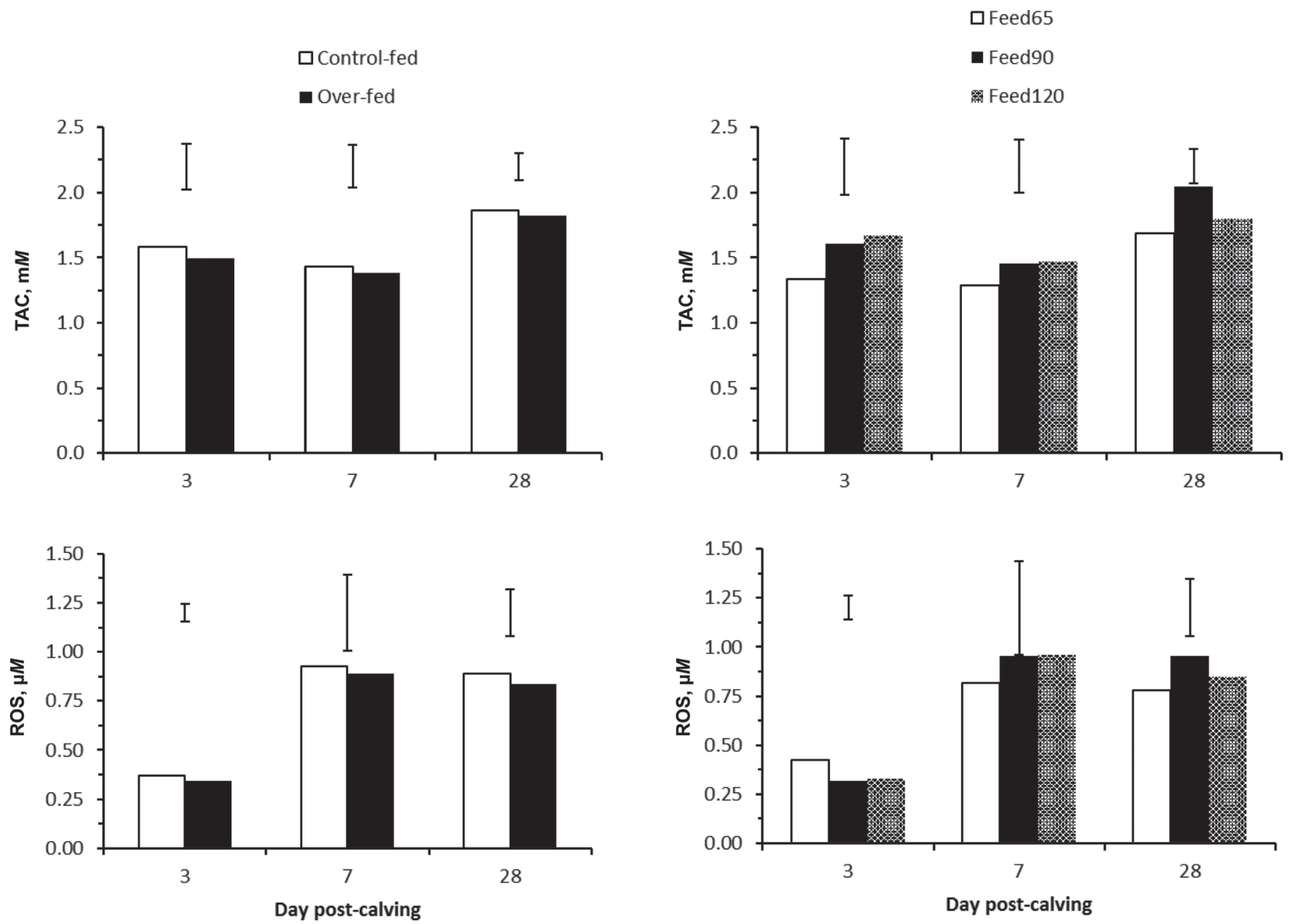

Figure 7. Effects of far-off and close-up feed allowance on the concentration of total antioxidant capacity (TAC) and reactive oxygen species (ROS) in blood during the first month postcalving. Feed allowance was managed during late lactation to create 2 different BCS groups at dry off. Subsequently, cows were either control-fed or over-fed during the far-off nonlactating period to maintain or gain BCS, respectively, and achieve the same BCS pre-calving. Each herd of cows was managed during the close-up transition period (i.e., $<4$ wk pre-calving) to achieve daily ME intakes during the 3 wk before calving (i.e., close-up period) equivalent to 65, 90, and $120 \%$ of their requirements (Feed65, Feed90, and Feed120, respectively; Roche et al., 2005). Error bars represent $2 \times \mathrm{SE}$ of the difference. 

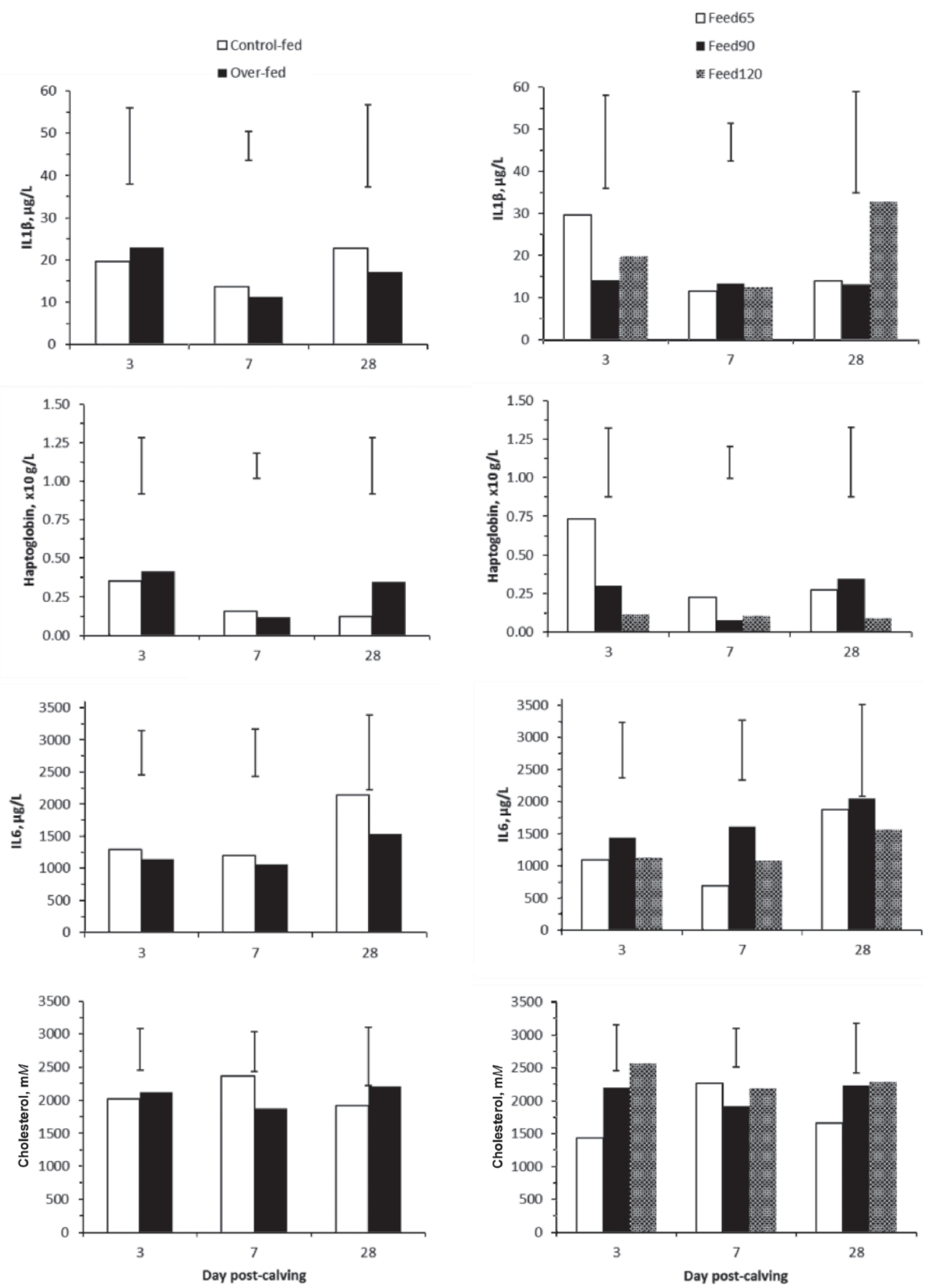

Figure 8. Effects of far-off and close-up feed allowance on the concentration of IL1 $\beta$, IL6, haptoglobin, and cholesterol in blood during the first month postcalving. Feed allowance was managed during late lactation to create 2 different BCS groups at dry off. Subsequently, cows were either control-fed or over-fed during the far-off nonlactating period to maintain or gain BCS, respectively, and achieve the same BCS pre-calving. Each herd of cows was managed during the close-up transition period (i.e., $<4$ wk pre-calving) to achieve daily ME intakes during the 3 wk before calving (i.e., close-up period) equivalent to 65, 90, and 120\% of their requirements (Feed65, Feed90, and Feed120, respectively; Roche et al., 2005). Error bars represent $2 \times \mathrm{SE}$ of the difference. 
were not at a greater risk of disease; they may, in fact, have been less likely to experience a malaise.

The results presented are not consistent with the negative effects on metabolic function during the first 10 DIM that were reported by Dann et al. (2006). Several reasons for the apparent inconsistency are possible, including differences in the degree of over-feeding in the far-off nonlactating period, which was much greater in the historical work. Dann et al. (2006) re- ported a $0.38 \mathrm{BCS}$ unit (5-point scale) increase in their over-fed treatment ( $150 \%$ NRC requirements) over a period of approximately $30 \mathrm{~d}$; this was compared with a 0.14 BCS unit increase in the treatment receiving $100 \%$ of requirements (100NRC). In comparison, the far-off_over-fed treatment cows in the current study gained the equivalent of $0.24 \mathrm{BCS}$ units over $35 \mathrm{~d}$ (5-point scale converted from 10-point scale; Roche et al., 2004) and this compared with 0.10 BCS units in the
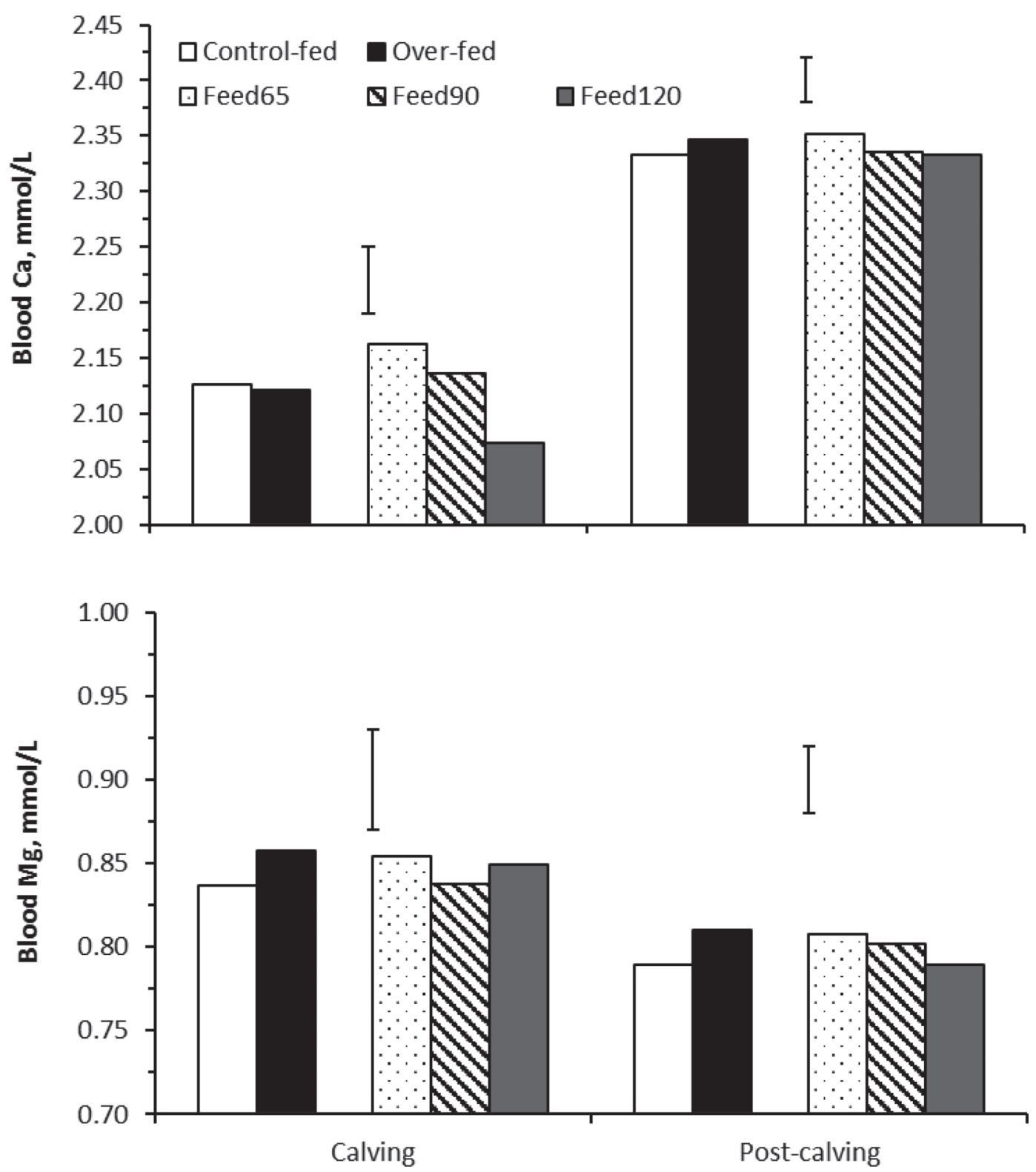

Figure 9. Effects of far-off and close-up feed allowance on blood $\mathrm{Ca}$ and $\mathrm{Mg}$ concentration at calving (i.e., of d 0-4 postcalving) and postcalving (i.e., average of d 7 and 14 postcalving). Feed allowance was managed during late lactation to create 2 different BCS groups at dry off. Subsequently, cows were either control-fed or over-fed during the far-off nonlactating period to maintain or gain BCS, respectively, and achieve the same BCS pre-calving. Each herd of cows was managed during the close-up transition period (i.e., $<4$ wk pre-calving) to achieve daily ME intakes during the 3 wk before calving (i.e., close-up period) equivalent to 65, 90, and $120 \%$ of their requirements (Feed65, Feed90, and Feed120, respectively; Roche et al., 2005). Error bars represent $2 \times \mathrm{SE}$ of the difference. 
far-off_control-fed treatment herd. Therefore, although the far-off_control-fed treatment in the current study was equivalent to the $100 \mathrm{NRC}$ treatment reported by Dann et al. (2006), the surplus energy partitioned to BCS gain in the over-fed far-off treatment group in their experiment was $\sim 60 \%$ greater than the cows in the far-off_control-fed treatment in the current experiment. The large difference in the scale of over-feeding in the far-off nonlactating cow is a plausible reason for the differences in metabolic state early postpartum.

Further reasons for the apparent inconsistency between the studies in the postpartum effects of the far-off feeding level strategy could be diet composition, calving BCS effects, or both. In addition to differences in DMI, differences were present in the starch and fatty acid content of the far-off treatment diets used by Dann et al. (2006): the over-fed cows had 62 and $82 \%$ higher starch and fatty acid content per kilogram of DM as well as a $38 \%$ greater DMI. Douglas et al. (2006) reported a 3-way interaction between level of nonlactating cow intake, diet composition (i.e., NFC vs. fat content), and time postpartum on blood fatty acid and BHB concentration after calving. The faroff treatment effects in the experiment reported here were due almost entirely to differences in DMI, with very little difference in diet composition (Table 2). It is plausible that the differences in diet composition in the study reported by Dann et al. (2006) may have interacted with the over-feeding to result in the reported metabolic dysfunction. A third potential reason for the apparent inconsistency may relate to calving BCS. The difference in calving BCS between the over-fed far-off cows and those fed to requirements in the study reported by Dann et al. (2006) was almost 4 times the difference in BCS evident between treatment groups in the experiment reported here ( $\sim 0.2$ vs. 0.05 BCS units; 5-point scale). Roche et al. (2013) highlighted the large effect of an equivalent difference in BCS on peripartum blood fatty acid and BHB concentrations. It is not possible to separate out the effect of far-off feeding level from pre-calving BCS in the historical work, but it is plausible that it was a contributing factor to the reported metabolic dysfunction. Although it is unlikely that the small difference in BCS in the current study (0.2 BCS units on the 10-point scale or 0.05 BCS units on a 5-point scale) would greatly affect the metabolic parameters measured, an effect cannot be discounted. What can be concluded, however, is that over-feeding during the far-off nonlactating period, in itself, did not negatively affect metabolic function postcalving.

In summary, although the effects of over-feeding in the far-off nonlactating period were different in our study to those reported by Dann et al. (2006), it is plausible that there is a threshold level of DMI in the far-off nonlactating period above which the periparturient cow's metabolic state is negatively affected and that the 2 studies' results are compatible. That said, from the perspective of a grazing dairy system, with feeds typically used, higher levels of ME intake than were achieved in the current study are unlikely, because DMI is limited compared with cows on TMR (Kolver and Muller, 1998). It is, therefore, appropriate to conclude that excessive feeding of grazing cows during the faroff nonlactating period is unlikely to cause metabolic dysfunction during the transition period.

\section{Close-Up Transition Period Nutrition and Postcalving Metabolic State}

The Feed65 cows presented with signs of an exacerbated inflammatory state peripartum, with higher Hp concentrations and lower cholesterol on d 3 postcalving and a lower albumin to globulin ratio through to 35 DIM, when measurements ceased. This is consistent with the trend for lower milk production in these cows, and is consistent with the hypothesis that there is a threshold level of underfeeding in the close-up transition cow, below which cow health and production are compromised postcalving. Results from both TMR-fed (Dann et al., 2006; Douglas et al., 2006) and pasture-fed (Roche et al., 2005, 2015) cows indicate that cows consuming 75 to $80 \%$ of their ME requirements during the 3 wk before calving have a superior metabolic profile postcalving to those consuming more than requirements. The data presented here indicate that feeding cows $65 \%$ of their requirements, however, negatively affects indicators of the functional state of the animal (i.e., functional welfare), such as cholesterol and albumin to globulin ratio (Loor et al., 2013), thereby reflecting an increased risk of postpartum disease and the likelihood of reproductive failure (Bertoni et al., 2003; Burke et al., 2010). These results are also consistent with the lower milk production during wk 2 postcalving and the trend for lower milk production until $7 \mathrm{wk}$ postcalving. Where severe restrictions have been imposed pre-calving previously, milk production has been less than in cows fed to between 80 and $100 \%$ of ME requirements (Roche et al., 2005), to ME requirements (Roche, 2007), and even to cows fed ME in excess of requirements (Hutton and Parker, 1973; Roche et al., 2005).

The effect of severe underfeeding (Feed65) on milk, fat, and protein yield, particularly during wk 2 and 3 postcalving $\sim 5 \%$ ), is similar in scale to the reduction reported by Roche (2007) and Roche et al. (2005), in which cows consumed 51 and $56 \%$ of ME requirements daily. Hutton and Parker (1973) reported a 15\% reduction in the yield of milk components during the first 56 DIM in identical twin cows that were either fed to 
maintain BW (i.e., negative energy balance because of gravid uterus growth during this period; Bell, 1995) or gain $\sim 0.7 \mathrm{~kg}$ of $\mathrm{BW} / \mathrm{d}$ (i.e., positive energy balance). Such a difference in BW change pre-calving would equate to a difference in ME intake of $\sim 50 \mathrm{MJ} / \mathrm{d}$ (Mandok et al., 2014), which is a severe restriction for the 300 to $350 \mathrm{~kg}$ of BW cows in their study. In addition, we do not know the BCS of their cows, which interacts with close-up level of feeding in affecting peripartum metabolic state (Roche et al., 2015). In conclusion, the collective recent research in feeding close-up pasturebased transition dairy cows indicate that if cows are a BCS of 5.0 (10-point scale; Roche et al., 2004) one month pre-calving, and if ME intake is restricted by up to $25 \%$ of their requirements, their metabolic profile after calving will be superior to cows fed less than $75 \%$ of requirements or more than $100 \%$ of requirements. A restriction more severe than $75 \%$ of requirements negatively affects milk production in early lactation and the blood markers of metabolic and inflammatory state indicate an increased risk of disease.

\section{Close-Up Feeding and the Risk of Milk Fever}

As previously noted (Roche et al., 2005; Roche, 2007; J. K. Drackley, personal communication), a reduction in ME intake during the close-up transition cow period increases blood $\mathrm{Ca}$ on the day of calving and during the $2 \mathrm{~d}$ following calving, and reduces the risk of both clinical and subclinical hypocalcemia. The reason for this effect of close-up feeding level on blood $\mathrm{Ca}$ is unclear and cannot be determined from this experiment. It could relate to a reduced intake of potassium, without a commensurate decline in $\mathrm{Mg}$ intake. It may also reflect a reduction in $\mathrm{Ca}$ intake pre-calving, with the duration of the experimental treatments sufficient to elicit an increase in gastrointestinal absorption (Braithwaite, 1974). Or, it may be an effect of level of ME intake on eucalcemic mechanisms that, as yet, has not been considered. Irrespective of mode of action, the data presented here and in previous experiments highlight a negative relationship between close-up transition cow DMI and peripartum blood Ca concentrations and the risk of hypocalcemia.

\section{CONCLUSIONS}

Overfeeding during the far-off nonlactating period in dairy cows grazing fresh pasture and supplemented with pasture silage does not appear to affect peripartum metabolic health, at least when cows are optimally conditioned at calving. Level of feeding in the close-up period pre-calving is important, with a slight restriction in ME intake (10-25\% of ME requirements) in optimally conditioned cows arguably beneficial for metabolic health and inflammatory state immediately postcalving. However, a restriction $\geq 35 \%$ of $\mathrm{ME}$ requirements reduced early lactation milk production and resulted in a blood profile indicative of increased metabolic stress and inflammation. The presented results provide confidence that rapid BCS gain in the far-off nonlactating cow, as is customary in grazing systems, is not detrimental to the subsequent health of the cow, but restricting cows by more than $25 \%$ of their ME requirements in the month before calving should be avoided.

\section{ACKNOWLEDGMENTS}

The authors thank Bruce Sugar, farm manager, Lye Farm, DairyNZ, and his capable team, as well as Stu Morgan, Kate Watkins, Ben Fisher, Kelly Collier, and Chris Roach for technical support, and Barbara Kuhn-Sherlock for statistical analysis and advice. This research was supported by New Zealand dairy farmers through DairyNZ Inc. (RD1403) and the Ministry of Business, Innovation, and Employment (DRCX1201).

\section{REFERENCES}

Agenas, S., E. Burstedt, and K. Holtenius. 2003. Effects of feeding intensity during the dry period. 1. Feed intake, body weight, and milk production. J. Dairy Sci. 86:870-882.

Bell, A. W. 1995. Early lactation regulation of organic nutrient metabolism during transition from late pregnancy to early lactation. J. Anim. Sci. 73:2804-2819.

Bertoni, G., E. Trevisi, A. Ferrari, and I. Archetti. 2003. Preliminary studies on compatibility between high yield levels and the wellbeing of dairy cows. Vet. Res. Commun. 27(Suppl. 1):639-641.

Boutflour, R. B. 1928. Pages 15-20 in Report of the World's Dairy Congress. June 26-July 12, 1928. Westminster, London, UK.

Braithwaite, G. D. 1974. The effect of changes of dietary calcium concentration on calcium metabolism in sheep. Br. J. Nutr. 31:319 331.

Burke, C. R., S. Meier, S. McDougall, C. Compton, M. Mitchell, and J. R. Roche. 2010. Relationships between endometritis and metabolic state during the transition period in pasture-grazed dairy cows. J. Dairy Sci. 93:5363-5373. https://doi.org/10.3168/jds.2010-3356.

Dann, H. M., N. B. Litherland, J. P. Underwood, M. Bionaz, A. D'Angelo, J. W. McFadden, and J. K. Drackley. 2006. Diets during far-off and close-up dry periods affect periparturient metabolism and lactation in multiparous cows. J. Dairy Sci. 89:3563-3577. https://doi.org/10.3168/jds.S0022-0302(06)72396-7.

Douglas, G. N., T. R. Overton, H. G. Bateman, H. M. Dann, and J. K. Drackley. 2006. Prepartal plane of nutrition, regardless of dietary energy source, affects periparturient metabolism and dry matter intake in Holstein cows. J. Dairy Sci. 89:2141-2157. https://doi. org/10.3168/jds.S0022-0302(06)72285-8.

Dyk, P. B. 1995. The association of pre-partum non-esterified fatty acids and body condition with peripartum health problems on 95 Michigan dairy farms. Masters thesis. Animal Science Department, University of Michigan, Ann Arbor.

Heiser, A., A. McCarthy, N. Wedlock, S. Meier, J. Kay, C. Walker, M. A. Crookenden, M. D. Mitchell, S. Morgan, K. Watkins, J. J. Loor, and J. R. Roche. 2015. Grazing dairy cows had decreased interferon- $\gamma$, tumor necrosis factor, and interleukin-17, and increased expression of interleukin-10 during the first week 
after calving. J. Dairy Sci. 98:937-946. https://doi.org/10.3168/ jds.2014-8494.

Holtenius, K., S. Agenäs, C. Delavaud, and Y. Chilliard. 2003. Effects of feeding intensity during the dry period. 2. Metabolic and hormonal responses. J. Dairy Sci. 86:883-891. https://doi. org/10.3168/jds.S0022-0302(03)73671-6.

Hutton, J. B., and O. F. Parker. 1973. The significance of differences in levels of feeding, before and after calving, on milk yield under intensive grazing. N. Z. J. Agric. Res. 16:95-104. https://doi.org/ 10.1080/00288233.1973.10421167.

Kolver, E. S., and L. D. Muller. 1998. Performance and nutrient intake of high producing Holstein cows consuming pasture or a total mixed ration. J. Dairy Sci. 81:1403-1411. https://doi.org/10.3168/ jds.S0022-0302(98)75704-2.

Loor, J. J., G. Bertoni, A. Hosseini, J. R. Roche, and E. Trevisi. 2013. Functional welfare-using biochemical and molecular technologies to understand better the welfare state of peripartal dairy cattle. Anim. Prod. Sci. 53:931-953. https://doi.org/10.1071/AN12344.

Loor, J. J., H. M. Dann, N. A. J. Guretzky, R. E. Everts, R. Oliveira, C. A. Green, N. B. Litherland, S. L. Rodriguez-Zas, H. A. Lewin, and J. K. Drackley. 2006. Plane of nutrition prepartum alters hepatic gene expression and function in dairy cows as assessed by longitudinal transcript and metabolic profiling. Physiol. Genomics 27:29-41. https://doi.org/10.1152/physiolgenomics.00036.2006.

Macdonald, K., and J. R. Roche. 2004. Condition Scoring Made Easy. 2nd ed. DairyNZ, Hamilton, New Zealand, Hamilton, New Zealand.

Mandok, K. M., J. K. Kay, S. L. Greenwood, J. P. McNamara, M. Crookenden, R. White, S. Shields, G. R. Edwards, and J. R. Roche. 2014. Efficiency of use of metabolizable energy for body weight gain in pasture-based, nonlactating dairy cows. J. Dairy Sci. 97:4639-4648. https://doi.org/10.3168/jds.2013-6912.

Roche, J. R. 2007. Milk production responses to pre- and postcalving dry matter intake in grazing dairy cows. Livest. Sci. 110:12-24. https://doi.org/10.1016/j.livsci.2006.08.016.
Roche, J. R., D. P. Berry, J. M. Lee, K. A. Macdonald, and R. C. Boston. 2007. Describing the body condition score change between successive calvings: a novel strategy generalizable to diverse cohorts. J. Dairy Sci. 90:4378-4396. https://doi.org/10.3168/jds.2006-729.

Roche, J. R., P. G. Dillon, C. R. Stockdale, L. H. Baumgard, and M. J. Vanbaale. 2004. Relationships among international body condition scoring systems. J. Dairy Sci. 87:3076-3079. https://doi. org/10.3168/jds.S0022-0302(04)73441-4.

Roche, J. R., N. C. Friggens, J. K. Kay, M. W. Fisher, K. J. Stafford, and D. P. Berry. 2009. Invited review: Body condition score and its association with dairy cow productivity, health, and welfare. J. Dairy Sci. 92:5769-5801. https://doi.org/10.3168/jds.2009-2431.

Roche, J. R., E. S. Kolver, and J. K. Kay. 2005. Influence of precalving feed allowance on periparturient metabolic and hormonal responses and milk production in grazing dairy cows. J. Dairy Sci 88:677-689. https://doi.org/10.3168/jds.S0022-0302(05)72732-6.

Roche, J. R., K. A. Macdonald, K. E. Schütz, L. R. Matthews, G. A Verkerk, S. Meier, J. J. Loor, A. R. Rogers, J. McGowan, S. R. Morgan, S. Taukiri, and J. R. Webster. 2013. Calving body condition score affects indicators of health in grazing dairy cows. J. Dairy Sci. 96:5811-5825. https://doi.org/10.3168/jds.2013-6600.

Roche, J. R., S. Meier, A. Heiser, M. D. Mitchell, C. G. Walker, M. A. Crookenden, M. V. Riboni, J. J. Loor, and J. K. Kay. 2015. Effects of precalving body condition score and prepartum feeding level on production, reproduction, and health parameters in pasturebased transition dairy cows. J. Dairy Sci. 98:7164-7182. https:// doi.org/10.3168/jds.2014-9269.

Sheehy, M., F. Mulligan, and A. Fahey. 2014. A comparison of serum metabolic profiles of dairy cows that maintained or lost body condition score 15 d before calving. J. Dairy Sci. 97(E Suppl.):283. (Abstr.) 